\title{
Application of 5P Teaching Method in China's Middle School English Teaching*
}

\author{
Rui Luo \\ Zhoukou Normal University, Zhoukou, China
}

\begin{abstract}
Directed by the traditional teaching methods, China's middle school English teaching pays much attention to passing down linguistic knowledge, ignoring students' learning motivation, which leads to students' inadequate ability of English application. 5P Teaching Method aims to improve students' self-learning ability and their language application ability, which requires teachers to change their roles and strengthen the interaction with students. Meanwhile, it can provide an active and lively environment for English teaching. This paper analyzes the application of 5P Teaching Method in middle school English teaching in China and proves its necessity and validity.
\end{abstract}

Index Terms — 5P Teaching Method, application, English Teaching

\section{INTRODUCTION}

Teaching methods are adopted to accomplish the task of teaching. Under the guidance of certain teaching methods, teachers guide students to acquire knowledge and skills, as well as to promote their physical and mental development. Teaching methods aim to achieve certain teaching goal and to complete certain teaching tasks, which are significant ways to solve problems in teaching activities. Teaching and learning is a kind of bilateral activity, thus teaching methods should also be bilateral which can explore the truth of both teaching and learning activities effectively. However, many traditional teaching methods usually attach importance to teachers' teaching while ignoring students' thinking and involvement. With the development of education, more and more teaching aims put forward higher requirements for teaching methods, so that there should be suitable reformation and innovation of teaching methods to keep pace with times.

5P Teaching Method refers to teachers' adoption of five procedures in the English teaching process, i.e. preparation, presentation, practice, production and progress. Based on the traditional 3P Teaching Method, it focuses on the objectives of the New National English Curriculum Standards in China and aims to improve students' self-learning ability, English language application ability and intercultural communication ability. The first procedure, preparation, aims to create a suitable and unique situation according to the teaching contents for students to enter naturally and actively. Then follow presentation, practice and production, which are all made in a student-involved atmosphere to arouse students' enthusiasm of learning. Progress is the last procedure, which can help students not only acquire but also apply what they have learned. There is no doubt that a suitable and scientific teaching method plays an important role in the language teaching process. A useful teaching method can not only attract students' interests to study, but also motivate teachers to make changes according to the development of education. In order to improve the current situation of learning English in China's middle school, the author puts forward the application of 5P Teaching Method, which is efficient to foreign language teaching.

\section{CuRrent Situation of China’s Middle School English Teaching}

In recent years, China's middle school English teaching has such problem as being eager for quick success and instant benefits. Teachers have the authority, while students lose the chance to learn by their own. Teachers take exam score as the main way to evaluate students' ability, while students' language application ability is ignored. The problem of exam-oriented education is still very serious, especially in the graduating class, which kills students' learning creativity and initiative. In addition, students are usually asked to do so much exercises for exams, that they don't have freedom to think on their own and don't have enough time to practice their practical English skills, including pronunciation, listening and speaking ability.

\section{A. Current Situation of English Pronunciation}

There are three key elements of English language learning in China's middle school, including vocabulary, grammar and speech. The former two elements are both showed through speech which plays a pivotal role in verbal as well as written communication. Learning speech can not only lay a solid foundation for learning English language, but also

\footnotetext{
${ }^{*}$ This paper, funded by The Teachers' Educational Program of Interactive Development Community in Eastern Henan Province in China, is the fruit of the program Research on the Pre-service Training of English Teachers' Information-based Teaching Skills in China's Middle School, Number: JYLD2018004.
} 
benefit students' communicative activities. However, many middle school teachers and students in China often ignore the relationship between speech and pronunciation. Students always recite English words one by one, instead of learning the pronunciation of words in speeches. This mechanical learning method can only get half the result with twice the effort.

Speech is the essence of English learning. To make a speech well, English learners should start from good pronunciation. From the beginning of learning English, students should be strict with themselves on pronunciation, and teachers should guide students to develop good pronunciation habit. Only in this way can students lay a solid foundation for better English learning in future.

In China's middle school, a common phenomenon is that students try very hard to improve their English pronunciation by recite single words. However, they ignore the stress and intonation which are important in communication.

According to a survey, there are mainly four reasons. First of all, English phonetic knowledge only accounts for a small proportion in the college entrance exam, thus it is not paid much attention to. Many students just focus on English reading, grammar, and vocabulary, while ignoring pronunciation, esp. stress and intonation. The second reason is that the arrangement of English learning contents is scattered without a coherent learning process. It will make students learn pronunciation skills in a fragmental way. The third reason is that some of our middle school English teachers don't attach too much importance to speech recognition. They only teach phonetic symbols instead of the important factor of phonemes. Thus students read words or sentences just according to their own memory without considering the phonetic symbols. Lastly, many students learn English pronunciation in a Chinese way. For instances, they usually use Chinese phoneme to pronounce English; they often ignore the stress, rhythm and intonation in English. Because of their Chinese study and living environment, many students tend to be influenced by Chinese pronunciation, while paying little attention to the stress, rhythm and intonation in English pronunciation.

\section{B. Current Situation of Listening and Speaking}

As a communication tool, English must be spoken to people. It is important to know what to say, when to say, and what kind of people we talk with, so we must understand the skills and methods clearly (Hedge, 2000). The essential purpose of acquiring a foreign language should be application and communication in which listening and speaking are in a vital position. Listening is the acquisition of language and the precondition of communication, while speaking is the application of language acquired and the key of communication. Therefore, in China's middle school English teaching process, the cultivation of students' listening and speaking ability ought to be emphasized. Rich and colorful teaching aids ought to be used to motivate students.

However, influenced by the traditional education model and the existing examination system, traditional English teaching methods usually lack of listening and speaking training in most areas of China, especially rural areas. Teachers still dominate the middle school English class without considering English as a communication tool to make students master the language. These traditional education model leads not only to a waste of time in English class, but also to students' passive acceptance of English knowledge. Some students are tired of English learning, and even give up learning English. In some middle schools, teachers add listening practice into English teaching, but this kind of listening course is only completed for examination, while ignoring the essence of listening English. Some teachers will put unit listening training together, or let students do some listening practice before exams, not for the cultivation of students' listening ability, but only for the exams.

Another phenomenon common in China is “dumb English". Listening and speaking training in middle school English teaching ignores the linguistic context and English culture, which limits the improvement of students' English communication ability. Meanwhile, with a large number of students in China's middle school classes, teachers cannot pay attention to every student and not every student has the chance to speak English in class. Thus, the cultivation of English listening and speaking ability is of great difficulty. In addition, some middle school English teachers' professional skills are not enough. Some teachers in the rural areas of China cannot even pronounce some basic words correctly. Middle school English teaching requires teachers not only to have excellent management ability, but also to have great English skills including listening, speaking, reading, writing, translating and viewing. What's more, English teachers should have the ability to design class activities. Teachers' organization and coordination ability also play an important role in the teaching process. In some rural area of China, middle school English teachers fail to cultivate students' ability to speak English, which leads to students' “dumb English". In addition, the current evaluation model in many areas cannot be adapted to the new curriculum reform, which causes a vicious circle of English learning. Some teachers in rural areas simply give up the training of students' listening and speaking ability. What's worse, some students are affected by teachers' incorrect pronunciation or by certain dialect. All in all, the current situation of students' listening and speaking ability is not optimistic at all.

\section{The Necessity of Adopting An EfFEctive TeAching Method}

In order to improve Chinese students' English self-learning ability and their English language application ability, it is necessary to adopt certain effective teaching method in middle school English class and to provide an active and lively environment for English teaching and learning. Teacher and students should work actively in the English classroom and 
have high quality of completing teaching tasks. Therefore, it is vital to make a correct choice and adopt effective teaching method. In many cases, some teachers' language teaching lacks of high efficiency, which is not because they don't have high language level but because they don't have appropriate or effective teaching method. Thus it is of great necessity for teachers to choose and use appropriate and effective teaching method.

The choice of teaching method should be based on the teaching aims, to effectively achieve different teaching aims. In addition, there are some other key factors need to be taken into consideration.

Firstly, teaching method should be adopted according to the teaching content. As for the different requirements of different teaching contents, there are certain flexibility and diversity considering the selection of teaching method. Teacher should have a deep understanding and systematic arrangement of certain teaching content while preparing the class. A proper and effective teaching method should be adopted in this process.

Secondly, teaching method should be adopted according to the features of students. It requires teacher to make a scientific and rational analysis of the students in general, as well as take some specific points into consideration. Teacher should keep a balance while choosing the suitable teaching method, so that students can achieve the most and acquire the language actively and naturally.

Thirdly, teaching method should be adopted according to the ability of teacher. Teacher should have an authentic and objective evaluation of his or her own ability. Teacher must fully understand and grasp the adopted teaching method and apply it into practice effectively. That is to say, teacher should consider own advantages and disadvantages and find out the appropriate teaching method.

Last but not least, teaching method should be adopted according to different teaching conditions and teaching environment. Under the guidance of teaching method, the class should also be conducted while making full use of the teaching environment and teaching conditions. So that the teaching activity can achieve its desired and best effect.

\section{Advantages of 5PTeaching Method}

5P Teaching Method is developed basing on 3P theory of English class organization. It refers to teachers' adoption of five procedures in the English teaching process, i.e. preparation, presentation, practice, production and progress. The basic arrangement of each class begins from preparation and ends with progress. Preparation includes review of the previous knowledge and leading in the new class, with a view to creating a suitable and unique situation according to the teaching contents for students to enter naturally and actively. Then teacher adopts suitable presentation ways to lead students into the new knowledge and helps students grasp the situation of new language contents. Teacher should try to create a language environment which is good for students to acquire the new knowledge through practice and production. Therefore, the last step can be achieved effectively and efficiently, that is, progress, which can help students not only acquire but also apply what they have learned. Generally speaking, the advantages of 5P Teaching Method in China's middle school English teaching could be summarized as follows.

Firstly, it can arouse students' initiative to learn.

Due to the long-running influence of examination-oriented education, teachers often adopt the teaching method of "indoctrination", imparting knowledge to students in a stereotyped way. Students only accept passively without any interaction with teachers. As time passes, students will lose interest in learning English. 5P Teaching Method encourages the communication between students and teachers, so that teachers can accurately learn the psychological needs of students and mobilize the classroom teaching atmosphere. 5P Teaching Method gives students so much time and space that students can participate in classroom activities and have the willingness to learn English. It makes students change from "I have to learn" to "I want to learn". Rich and vivid classroom activities motivate students to participate and to cooperate actively and efficiently. Students can acquire language skills of high efficiency in the process of taking part in activities. In addition, students are guided to make objective and rational self-reflection each time in the progress part, which is of great significance for their all-round improvement.

Secondly, it can train and develop students' critical thinking ability.

Guided by 5P Teaching Method, teachers pay much attention to effective teaching design and raise suitable topics for students to think and discuss. In the process of group discussion, pair work and presentation, students can improve their critical thinking ability while at the same time applying English knowledge to speaking and writing. From students' performance, teachers can reflect effectively and improve their teaching design in time according to the feedback. $5 \mathrm{P}$ Teaching Method gives students enough time to think on their own. In order to ensure that students can acquire English language knowledge and application skills, the method focuses on teacher's guidance and students' active participation. Students are divided into several groups. Teacher gives time for students to conduct group discussion. After that, there should be at least one student in each group to make the presentation in front of the whole class to give their group's opinion. Through the exchanges and cooperation with each other, they can have divergent thinking, open their mind and broaden their horizons. It is very good to encourage students' enthusiasm and creativity.

Thirdly, it can create a good language learning environment for students.

The universal phenomenon for Chinese students to learn a foreign language is the lack of language learning environment. Students in many middle schools in China have few chances to contact with people from English-speaking countries. Their learning materials are mainly confined to textbooks. As is known to us all, children are largely affected by mother tongue from they are born. While their childhood "language acquisition system" is 
gradually losing as they are growing up. So it is especially important to provide the English learning environment for middle school students to arouse their English language acquisition system. Although China is in high-speed development nowadays, in quite a number of middle schools in China, the English education is still relatively backward without advanced teaching equipment and qualified faculty. In view of the above situation, the main way for middle school students to learn a foreign language in China is still classroom learning. Thus it is essential to reform the old teaching structure and apply 5P Teaching Method so as to give students plenty of opportunities to practice English, to cultivate their ability of using English in real or simulated situation, and to practice spoken English in a very interesting and relaxing environment. 5P Teaching Method can create all kinds of teaching environment for students, so that they have various chances to show their talents. In the process of applying 5P Teaching Method, students can put English into real practice. For instance, in certain teaching contexts, the teacher asks students to put the English text into a small drama. This allows students to practice speaking English in a very interesting and real environment.

Fourthly, it can help to cultivate students' cooperative competence.

Cooperative learning is another crucial factor to middle school English learning in China. In the practice and production parts of 5P Teaching Method, group discussions and pair work are the essential classroom activities. Teacher assigns some tasks for students to express their opinions during group discussions or pair work. Students are willing to participate in such tasks actively and enthusiastically. After discussion with group members or partners, students' understanding of English language would be more reasonable and comprehensive. Thus the advantages of cooperative learning are very obvious in comparison with the traditional competitive learning. What's more, the relationship between students themselves and the teacher are improved significantly through discussion and cooperation. Students' cooperative competence can be enhanced largely, which is beneficial not only to their English learning but also to their future career, for cooperation is vital in all walks of life in our modern society.

Fifthly, it adopts multi-media teaching aids to help students' learning.

In the teaching process of English in China's middle school, multi-media aids are commonly used under the guidance of 5P Teaching Method. Multi-media teaching aids are featured by the suitable use of Internet, computer and other modern technology, which can give students a deep impression during the English learning process. For example, in the presentation part, teacher can download some pictures or videos from the Internet related with the English learning content. Those vivid pictures or videos can give students rich feelings of language and culture. All these are beneficial to the development of students' independent thinking ability and creativity. Another typical example is the application of WeChat group in the progress part. After class, students can share their feedbacks instantly in their WeChat group, where they can also give their opinions on certain topics freely. Multi-media aids are necessary to China's middle school English teaching in the modern society.

\section{The Roles of Teacher And Students in 5P TEaching Method}

In the current curriculum reform in China, students' self-learning ability, cooperation awareness and inquiry spirit are advocated. This is not only a matter of new idea, but also a matter of new teaching method. Traditionally, in China's middle school English class, teacher imparts knowledge to students, and students receive those contents passively. However, we need to break the traditional teacher-centered concept and guide students to learn actively on their own. That is to say, students should be the master of learning. An effective English class should involve students in comprehending, manipulating, producing or interacting in the target language, and their attention should principally focused on meaning rather form (Nunan, 1999). Therefore, the roles of teacher in 5P Teaching Method should be adjusted as follows.

Firstly, teacher is the reformer of teaching methods. With the rapid development of society, teacher also needs to keep up with the times. Teachers are required to have sensitive insight into the trend of current teaching reform in China, and return the initiative of learning English back to students. Harmer (1993) defines teacher's roles as "controller, assessor, organizer, prompter, participant and resource-provider" (Harmer, 1993, p.201). Traditionally, the rigid regular consciousness makes teacher the inculcator and supervisor while neglects the full play of students' entity and potential. Thus, teacher should transform from the inculcator of knowledge into the organizer, guide as well as participant of kinds of learning activities. The classroom is no longer teacher's stage alone, but students' free platform to show themselves. To become a qualified English teacher in the new era, the first thing for middle school English teacher in China is to update the teaching concept, and then to reform the classroom teaching with the realization of effective English teaching method.

Secondly, teacher is the designer of classroom teaching. To improve the efficiency of English classroom teaching, teacher should first pay attention to students' personality and design the teaching tasks or activities based on students' character and interests. The efficient teaching design should stimulate students' enthusiasm of learning English and should be in accordance with teaching aims including knowledge aims, ability aims and emotional aims. English teacher, as the designer of English teaching, should take knowledge and skill, process and method, emotion attitude and values into consideration. Through the teaching design, teacher should help students to reach their potential to the full extent, which not only can stimulate students' interest in English learning, but also is beneficial to achieve the teaching aims. It requires English teacher to design the classroom activities and tasks based on the usage of language in the real context, so that students can apply what they have learned into practice naturally. 
Thirdly, teacher is the conductor of the whole class. A class in middle school is just like an orchestra. In order to have an excellent performance, the organization and direction of a qualified and responsible conductor is of great significance. Thus in the middle school English teaching process, teacher should guide students to build a scientific and effective classroom teaching environment together. Students should become the subject of English learning, participate in the class teaching process and cooperate with each other to achieve a better performance. Teacher should be full of passion to involve the whole class in the English learning, to motivate students' autonomic learning and cooperative learning. Under the guidance of 5P Teaching Method, teacher should be very good at organizing discussion in China's middle school English class. English is a tool for communication. In the learning process of English articles, students should discuss the main topics and related issues. It can not only deepen students' understanding of the works, but also improve their English skills in a comprehensive way, including listening, speaking, reading, writing, translating and viewing. It deserves to be mentioned that teacher should have good control of the time, and help students to discuss freely but not blindly. The freedom of students' performance should always be under teacher's guidance and directions.

\section{CONCLUSION}

In the process of applying 5P Teaching Method into China's middle school English teaching, teachers should notice that this method is completely different from the traditional English teaching method in China. 5P Teaching Method refers to teachers' adoption of five procedures in the English teaching process, i.e., preparation, presentation, practice, production and progress. In the first step, preparation, review and warm-up are included, in order to remind students of what have learnt and introduce students to the new contents in a natural way. For the presentation part, teachers do their best to present the new knowledge in an interesting and acceptable way so that students can acquire the language points and cultural notes as effective as possible. Practice makes perfect, thus it is essential for teachers to design various exercises for students to practice. Then colorful productions would appear under teachers' guidance. In addition, teachers should give some necessary tips and hints, and make suitable comments, which is of great significance to students' progress. To sum up, effective application of 5P Teaching Method can improve students' English skills and their language application ability in a comprehensive way. But is also requires English teachers in China to improve themselves in various aspects, including solid knowledge of English language and culture, intercultural competence, the ability of teaching design and communication with individual students. Only in this way can they make full use of 5P Teaching Method and turn the English classroom into students' platform for improving kinds of English skills and comprehensive competence.

\section{REFERENCES}

[1] Harmer, J. (1993). The Practice of English Language Teaching. London: Longman.

[2] Hedge, T. (2000). Teaching and Listening in the Language Classroom. Oxford: Oxford University Press.

[3] Hymes, D. H. (1979). Communicative Approach to Language Teaching. Oxford: Oxford University Press.

[4] Nunan, D. (2000). Design Tasks for the Communicative Classroom. Beijing: People's Education Press.

[5] Nunan, D. (1999). Language Teaching Methodology --- A Textbook for Teacher. New York: Prentice Hall.

[6] Richards, J. C. \& T. S. Rodgers. (2000). Approaches and Methods in Language Teaching. Beijing: Foreign Language Teaching and Research Press.

[7] Ur, P. (1984). Teaching Listening Comprehension. Cambridge: Cambridge University Press.

Rui Luo, was born in 1987, master's degree, a lecturer in the College of Foreign Languages, Zhoukou Normal University, China. Her research field is English Linguistics and English Teaching Studies. 